\title{
The Effect of Collectivism Diversity towards Multicultural Teamwork Performance Among Restaurant Employees
}

\author{
Zahidah Ab Latif \\ Universiti Pendidikan Sultan Idris, Tanjong Malim, Perak Darul Ridzuan 35900, Malaysia \\ *Corresponding author, e-mail: zahidah@ftv.upsi.edu.my
}

\begin{abstract}
Diversity is now an important factor that impacted workforce performance. Currently, as having a diverse workforce, Malaysia is depending heavily on foreign workers in the hospitality industry. This study examined a conceptual model investigating the effect of diversity particularly collectivism in influencing multicultural teamwork performance. A self-administered questionnaire was conducted in casual ethnic restaurants in Klang Valley, Malaysia. The findings disclosed that collectivism diversity had a significant influence on multicultural teamwork performance. This study is the first to assess cultural value diversity particularly collectivism value on teamwork performance. This study verified that cultural value diversity increases multicultural teamwork performance in the restaurant context in relation to collectivism. The significant results deepen our understandings of the detailed relationships among the variables. In addition, by providing the current phenomena in workforce industry, this study provides insights to the restaurant managers in handling diversity among multicultural employees.
\end{abstract}

Keywords: Collectivism diversity, Cooperation, Diversity, Multicultural teamwork performance, Production.

\section{INTRODUCTION}

Great emphasis has been paid to the effects of cultural diversity on team performance as the numbers of organizations using teams as their fundamental structure to boost their competitive advantage are increasing (Barak, 2013; Dienes \& Velte, 2016). Workforce diversity and cultural differences are crucial for the organization's performance that capitalizing this culture. Diversity, defined as distinctly different in group ascribed characteristics such as ethnic background, gender, and cultural significance (Eze et al., 2019). In other words, multicultural workforce diversity is defined as the multitude of the individual differences and similarities that exist among the people working as a team in an organization (Kreitner \& Kinichi, 2004). From the context of this study, the cultural differences among employees are observed by a way that a team operates in unity from the value of collectivism diversity.

Recent research has discussed adverse effects of workforce diversity on the performance of the team. Some studies predicted that multicultural workforce has resulted better in problem-solving and decision making, which interpreted as the advantage of having multiple perspectives and views, thus resulted in increased team performances (Alesina \& LaFerrara, 2005; Timmermans, Ostergaard, \& Kristinsson, 2011). On the other hand, others argue that dissimilarities in cultures and languages negatively influenced teamwork performance within an organization because employees share lack of experiences and common ideas, poor communication, less cooperation, and create conflicts among team members (Kahane, Longley, \& Simmons, 2013; Lazear, 1999). Thus, there is no consensus on diversity's impact towards teamwork performance. Hence, more extensive research is needed to examine the impact of cultural value diversity on team outcomes.

Malaysia has a diverse population as more than 3.3 million people have recently migrated from poor neighboring countries such as Indonesia, Myanmar, and Philippines (Rajagopal, 2019). Service sectors including restaurants and hotels depend heavily on 
foreign workers due to the migration (Hamid, 2009). The growing numbers of immigrants in Malaysia contribute to the emergence of diverse culture, value, language among employees, and multicultural team working environments. However, there has been little research concerning the effects of diversity on service industries. Therefore, a research is needed to further investigate the workforce diversity in Malaysian hospitality realms.

To address this dearth in the literature, this study chose Malaysian's employees who work for restaurants. The purpose of this research was to compare and determine whether there are statistically significant differences between the means of restaurants in Malaysia in relations of cultural value diversity (i.e. collectivism) and multicultural teamwork performance (MCTP).

\section{RESEARCH METHOD \\ A conceptual framework}

A proposed model in the current study was developed to understand to what extent are the mean differences among restaurants in average MCTP due to restaurants differences in collectivism scores (See Figure 1). The collectivism variable reflects the employees' ratings of their cultural value diversity. Similarly, the MCTP was assessed through two aspects of productivity and cooperation.

Numerous studies have been conducted to explore the impact of cultural differences on team performance (Barak, 2013; Bhadury, Mighty, \& Damar, 2000; Higgs, 1996; Lavaty $\&$ Kleiner, 2001). Most of them focus on the negative influence of the relationship between diverse culture and performance in the organizations. For instance, Kirkman \& Shapiro (2005) suggested that diverse team are less likely to be cohesive and be able to reach consensus among team members, thus contribute to decrease team performance. However, recent study by Kahane, Longley, \& Simmons (2013) found that mixing local and foreign employees stimulate positive outcome to the workforce.

People from different ethnic backgrounds have different attitudes, values, and norms. With a diverse teamwork, it may contribute to increase an organization's performance. Noordin \& Jusoff (2010) identified that collectivistic societies have high loyalty towards the organization and take action jointly as a group that increased team performance. When individuals engage in a performance-related task, they typically take actions to reach certain standards. These actions may include directly altering their behavior in order to more closely match a standard (Tsui \& Ashford, 1994). These strategies require that the individuals changed their environment in some way.

Tröster, Mehra, \& Knippenberg (2014) suggested that there is a significant relationship between cultural diversity and teamwork performance. They found that employees from different cultural background or heterogeneity increase the effectiveness of a team and ameliorate team's ability to perform well during production hours. The results of their study supported the positive relationship between the two constructs. Therefore, the following hypothesis is proposed.

H1: There is a significant effect of collectivism on predicting multicultural teamwork performance.

Latif, Z. A. (2019). The Effect of Collectivism Diversity Towards Multicultural Teamwork Performance Among Restaurant Employees. Journal of Vocational Education Studies, 2(2), 91-100. DOI: https://doi.org/10.12928/joves.v2i2.1180. 


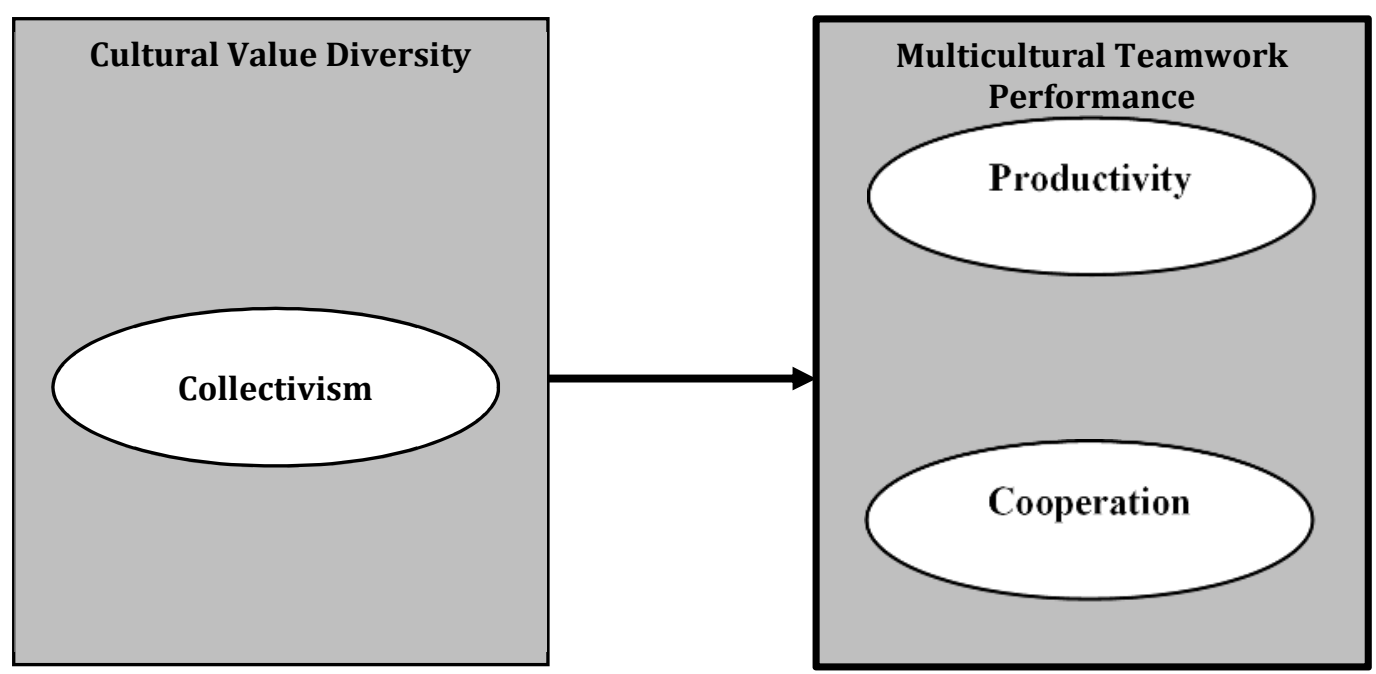

Figure 1. Proposed model

\section{Instruments}

The survey questionnaire consisted of three sections. The first section included a total of 11 items to measure the cultural value diversity in the perspective of collectivism (Kirkman \& Shapiro, 2005, Maznevski et al., 2002). The second part consisted of 19 items to evaluate work performance in the two dimensions of productivity and cooperation (Kirkman \& Shapiro, 2005; Campion, Medsker \& Higgs, 1993). This study used a 5-point Likert scale ranging from 1 (strongly disagree) to 5 (strongly agree). The last section included demographic information of respondents.

\section{Pilot study}

A pilot test was conducted to 30 employees in dining and cafeterias at a University in Malaysia in March 2010 to ensure that the wording of the questionnaire was clear. Some items were modified to enhance clarity of the questions. The reliability of all measurements was above the cutoff of 0.70 , which indicated good internal consistency (Nunnally, 1978).

\section{Sampling and data collection}

The target sample was employees who worked for casual ethnic restaurants with a mixture of foreign and local workers. A self-administered questionnaire was distributed to the employees in 24 casual ethnic restaurants in the district of Petaling. The chosen restaurants were identified as having a balanced number of local and foreign workers. A total of 240 questionnaires were distributed and 150 responses were returned, corresponding to a response rate of $62.5 \%$. The complete responses received from 15 restaurants in which 10 employees are nested under each participating restaurant. The survey was open for two months between June 1st and July 31st, 2019.

\section{Data analysis}

The IBM SPSS Statistics 23 was utilized by conducting descriptive analysis to obtain statistics including mean, standard deviation, frequency, and percentage to summarize the data. Internal consistency of each identified construct was calculated to evaluate instrument reliability through Cronbach's alpha values. Next, the SAS Enterprise Guide 7.1 was employed to test the hypothesized relationship based on the three-step analysis as 
follows. The first step involved testing a null model through one-way ANOVA with random effects to predict the participant's multicultural teamwork performance. The second step involved testing a Level 1 model by adding employees' characteristic as a predictor of MCTP. The final step involved testing a Level 2 model by adding restaurant level variable as predictor of MCTP.

\section{RESULTS AND DISCUSSION Profile of respondents}

Of the participants in the study, 52 percent of the participants were male and 48 percent were female, most are between 16 and 30 years old (88 percent). More than half of the participants have foreign nationality (64 percent). The majority of the respondents completed tertiary education (54 percent) with a large majority has below 3 years of organizational (86.7 percent) and job tenure (68.7 percent). Table 1 shows the profile of the respondents.

Table 1. Profile of respondents

\begin{tabular}{|c|c|c|}
\hline & Frequency (N) & Percentage (\%) \\
\hline \multicolumn{3}{|l|}{ Gender } \\
\hline Male & 78 & 52.0 \\
\hline Female & 72 & 48.0 \\
\hline \multicolumn{3}{|l|}{ Age } \\
\hline $16-20$ years old & 16 & 10.7 \\
\hline $21-25$ years old & 69 & 46.0 \\
\hline $26-30$ years old & 48 & 32.0 \\
\hline $31-35$ years old & 9 & 6.0 \\
\hline $36-40$ years old & 8 & 5.3 \\
\hline \multicolumn{3}{|l|}{ Nationality } \\
\hline Bangladesh & 19 & 12.7 \\
\hline Philippines & 21 & 14.0 \\
\hline Indonesia & 22 & 14.7 \\
\hline Malaysia & 54 & 36.0 \\
\hline Nepal & 13 & 8.7 \\
\hline Myanmar & 12 & 8.0 \\
\hline Thailand & 9 & 6.0 \\
\hline \multicolumn{3}{|l|}{ Education Level } \\
\hline Primary school & 17 & 11.3 \\
\hline Secondary/High school & 52 & 34.7 \\
\hline Certificate & 29 & 19.3 \\
\hline Diploma & 40 & 26.7 \\
\hline Bachelor/Degree & 12 & 8.0 \\
\hline \multicolumn{3}{|l|}{ Organizational Tenure } \\
\hline$<1$ year & 66 & 44.0 \\
\hline $1-3$ years & 64 & 42.7 \\
\hline $4-6$ years & 12 & 8.0 \\
\hline 7-9 years & 8 & 5.3 \\
\hline \multicolumn{3}{|l|}{ Job Tenure } \\
\hline$<1$ year & 36 & 24.0 \\
\hline $1-3$ years & 67 & 44.7 \\
\hline 4-6 years & 27 & 18.0 \\
\hline $7-9$ years & 18 & 12.0 \\
\hline$>10$ years & 2 & 1.3 \\
\hline
\end{tabular}

Latif, Z. A. (2019). The Effect of Collectivism Diversity Towards Multicultural Teamwork Performance Among Restaurant Employees. Journal of Vocational Education Studies, 2(2), 91-100. DOI: https://doi.org/10.12928/joves.v2i2.1180. 


\section{Descriptive analysis}

The descriptive analysis of cultural value measure and multicultural teamwork performance measures within restaurants were analysed. In order to verify the degree of the agreement of the variables, mean scores were referred. The mean score from 1.99 and below is rated as 'low', while mean score ranging from 2.00 to 3.99 is classified as 'moderate' and mean score from 4.00 and above is rated as 'high'. The findings indicated that the mean for collectivism and MCTP measures had a moderate and high scores. The mean values (M) and standard deviation (SD) for both sections are shown in Table 2.

Table 2. Descriptive analysis results

\begin{tabular}{|c|c|c|c|}
\hline Latent variables and items & $\mathbf{N}$ & Mean & SD \\
\hline \multicolumn{4}{|l|}{ Collectivism } \\
\hline $\begin{array}{l}\text { 1. The performance of one's workgroup or unit is more } \\
\text { important than one's own individual performance }\end{array}$ & 150 & 4.08 & .959 \\
\hline $\begin{array}{l}\text { 2. Society works best when people willingly make sacrifices } \\
\text { for the good of everyone }\end{array}$ & 150 & 4.05 & .805 \\
\hline $\begin{array}{l}\text { 3. Good team members subordinate their own goals and } \\
\text { thoughts to those of the team }\end{array}$ & 150 & 3.81 & .960 \\
\hline $\begin{array}{l}\text { 4. Every person has a responsibility for all others in his or } \\
\text { her workgroup or unit }\end{array}$ & 150 & 4.22 & .881 \\
\hline 5. It is important not to stand out too much in a team & 150 & 3.47 & 1.072 \\
\hline $\begin{array}{l}\text { 6. Every person on a team should be responsible for the } \\
\text { performance of everyone else on the team }\end{array}$ & 150 & 3.83 & 1.085 \\
\hline $\begin{array}{l}\text { 7. Working with a group is better than working } \\
\text { alone }\end{array}$ & 150 & 4.00 & .976 \\
\hline $\begin{array}{l}\text { 8. People in a group should realize that they } \\
\text { sometimes are going to have to make sacrifices for the } \\
\text { sake of the group's well-being }\end{array}$ & 150 & 4.03 & .886 \\
\hline $\begin{array}{l}\text { 9. An employee should accept the group's decision even } \\
\text { when personally he or she has a different opinion }\end{array}$ & 150 & 3.97 & .930 \\
\hline $\begin{array}{l}\text { 10. Problem solving by groups gives better results than } \\
\text { problem solving by individuals }\end{array}$ & 150 & 4.07 & .928 \\
\hline $\begin{array}{l}\text { 11. The needs of people close to me should take priority } \\
\text { over my personal needs }\end{array}$ & 150 & 3.47 & 1.014 \\
\hline
\end{tabular}

Latif, Z. A. (2019). The Effect of Collectivism Diversity Towards Multicultural Teamwork Performance Among Restaurant Employees. Journal of Vocational Education Studies, 2(2), 91-100. DOI: https://doi.org/10.12928/joves.v2i2.1180. 


\begin{tabular}{|c|c|c|c|}
\hline Latent variables and items & $\mathbf{N}$ & Mean & SD \\
\hline \multicolumn{4}{|l|}{ Productivity } \\
\hline 1. Meets or exceeds its goals & 150 & 3.77 & .84 \\
\hline 2. Completes its tasks on time & 150 & 3.93 & .93 \\
\hline $\begin{array}{l}\text { 3. Makes sure that products and services meet or exceed } \\
\text { quality standards }\end{array}$ & 150 & 4.07 & .80 \\
\hline 4. Responds quickly when problems come up & 150 & 4.03 & .882 \\
\hline 5. Is a productive team & 150 & 3.84 & 913 \\
\hline 6. Successfully solves problems that slow down our work & 150 & 3.76 & .960 \\
\hline $\begin{array}{l}\text { 7. Have great confidence that the team can perform } \\
\text { effectively }\end{array}$ & 150 & 3.91 & .889 \\
\hline 8. Can take on nearly any task and complete it & 150 & 3.87 & .86 \\
\hline $\begin{array}{l}\text { 9. Believes it can be extremely good at producing high- } \\
\text { quality work }\end{array}$ & 150 & 3.88 & .88 \\
\hline 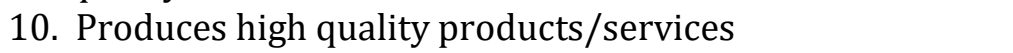 & 150 & 3.98 & .82 \\
\hline $\begin{array}{l}\text { 11. Sets its own prod } \\
\text { Team Cooperation }\end{array}$ & \multicolumn{2}{|c|}{ Team Cooperation } & .83 \\
\hline $\begin{array}{l}\text { 12. Members of my tean } \\
\text { information with oth }\end{array}$ & 150 & 3.71 & $\begin{array}{c}1.02 \\
0\end{array}$ \\
\hline $\begin{array}{l}\text { 13. Teams enhance the communication among people } \\
\text { working on the same product }\end{array}$ & 150 & 3.78 & .954 \\
\hline 14. Mer & 150 & 3.97 & .89 \\
\hline 15. Eve & 150 & 3.93 & .87 \\
\hline $\begin{array}{l}\text { 16. No one in my team depends on other team members to } \\
\text { do the work for them }\end{array}$ & 150 & 3.68 & $\begin{array}{c}1.03 \\
2\end{array}$ \\
\hline $\begin{array}{l}\text { 17. Nearly all the members on my team contribute equally to } \\
\text { the work }\end{array}$ & 150 & 3.81 & .903 \\
\hline $\begin{array}{l}\text { 18. Members of my team help each other out at work when } \\
\text { needed }\end{array}$ & 150 & 3.99 & .807 \\
\hline $\begin{array}{l}\text { 19. My team is very flexible in term of changes in } \\
\text { membership }\end{array}$ & 150 & 3.88 & .926 \\
\hline
\end{tabular}

\section{Reliability analysis}

Taking identification of appropriate alpha value into consideration, Hair et al. (2007) supported by Pallant (2010), suggested that the ideal value of Cronbach's alpha coefficient of a scale should 0.70 as a minimum to indicate high internal consistency. Looking at all the values ranges from 0.75 to 0.87 , these constructs had a very good reliability strength. Table 3 exhibits the reliability analysis results of each construct.

Table 3. Reliability analysis results

\begin{tabular}{|c|c|c|}
\hline Variables & $\begin{array}{c}\text { Number of } \\
\text { Items }\end{array}$ & Cronbach's Alpha \\
\hline \multicolumn{3}{|l|}{ Cultural Value Diversity (IV) } \\
\hline Collectivism & 11 & .751 \\
\hline \multicolumn{3}{|c|}{ Multicultural Teamwork Performance (DV) } \\
\hline Team Productivity & 11 & .866 \\
\hline Team Cooperation & 8 & .804 \\
\hline
\end{tabular}

Latif, Z. A. (2019). The Effect of Collectivism Diversity Towards Multicultural Teamwork Performance Among Restaurant Employees. Journal of Vocational Education Studies, 2(2), 91-100. DOI: https://doi.org/10.12928/joves.v2i2.1180. 


\section{Model analysis}

The simplest possible hierarchical linear model is equivalent to a one-way ANOVA with random effects or also known as a null model. Estimating the one-way ANOVA model is often beneficial as a preliminary step in a hierarchical data analysis. It provides information about the outcome variability at each of the two levels. The $\sigma 2$ parameter represents the within-group variability, while $\tau 00$ captures the between-group variability. This model yields an equation of Yij $=\beta 0 \mathrm{j}+$ rij that refers as fully unconditional (i.e. null model) in that no predictors are specified at either level 1 or 2 . An essential parameter associated with the one-way ANOVA with random effects is the intraclass correlation coefficient (ICC). The formula for this coefficient is $\rho=\tau 00 /(\tau 00+\sigma 2)$ that measures the proportion of the variance that is between the level-2 units (Raudenbush \& Bryk, 2002).

A random intercept or null model was analyzed (See Table 4), wherein no predictors at the individual or restaurant level involved in comparing 15 restaurants on the MCTP. An analysis of variance showed that the effect of 15 restaurants on MCTP was statistically significant at $\beta(14)=0.39$, S.E $=0.08, t=49.44, \rho<0.0001$. Later, the ICC for the MCTP variable was computed that yields $\rho=0.25$. This indicated a weak interrater reliability where the variability between subjects is small. As according to Norton and Olds (1996), ICC will be close to 1 if there is high variability between subjects and values close to 1 are desirable. In addition, from the ICC coefficients, the reliability coefficients also computed with the formula $\lambda=\tau 00 /(\tau 00+\sigma 2 / \tilde{n}), \lambda=0.77$.

In the second step of the analysis, level 1 predictor model was conducted. Level 1 variable, collectivism was included as a predictor of MCTP. After conducting an analysis of level 1 , collectivism was found not to be a significant predictor for multicultural teamwork performance at $\beta(134)=0.31, \mathrm{~S} . E=0.12, \mathrm{t}=2.55, \mathrm{p}=0.01$. The finding implied that collectivism values among employees were not given significant impact on the teamwork performance.

In the final procedure, level 2 predictor model was analyzed. Restaurant level variable of collectivism was added to test whether it plays a role as predictor of MCTP. The findings showed that mean collectivism was marginally significant predictor for MCTP at $\beta$ $(13)=1.2, \mathrm{~S} . \mathrm{E}=0.32, \mathrm{t}=3.73, \mathrm{p}=0.003$. This finding means, any one point increases in mean collectivism value, there is 1.2 increases in the mean level of MCTP for the 15 restaurants. Given the relationship between collectivism diversity on multicultural teamwork performance were proven to be significant, it means that the hypothesis (H1) was accepted. This is consistent with previous studies that the majority of Asian people are collectivists, thus they could easily adapt the diverse environment in the restaurant (e.g. Kirkman \& Shapiro, 2005; Noordin \& Jusoff, 2010).

Table 4. Model Results

\begin{tabular}{lccccc}
\hline \multicolumn{1}{c}{ Effect } & DF & Estimate & S.E & t & p \\
\hline Intercept & 14 & 3.88 & .08 & 49.44 & $<.0001$ \\
C_Collectivism & 134 & .31 & .12 & 2.55 & .01 \\
Mean & 13 & 1.20 & .32 & 3.73 & .003 \\
Collectivism & & & & & \\
\hline
\end{tabular}

Latif, Z. A. (2019). The Effect of Collectivism Diversity Towards Multicultural Teamwork Performance Among Restaurant Employees. Journal of Vocational Education Studies, 2(2), 91-100. DOI: https://doi.org/10.12928/joves.v2i2.1180. 


\section{CONCLUSION}

The research results showed the impact of cultural value diversity towards multicultural teamwork performance. First, collectivism diversity had a significant influence on multicultural teamwork performance. This implies that restaurant employees from different nationalities and collectivism cultures could efficiently work together as a productive team. Although they have difficulties understanding language and adapting to a new culture, employees believed that if they worked in a group, most problems could be overcome. This experimental result has been supported by a previous study that collectivism value could ameliorate team performance (Noordin \& Jusoff, 2010).

This study is the first to assess cultural value diversity particularly collectivism value on teamwork performance. This study verified that cultural value diversity increases multicultural teamwork performance in the restaurant context in relation to collectivism. The significant results deepen our understandings of the detailed relationships among the variables. The findings revealed that the coefficients were significant except for the level 1 model. These results indicated that overall, collectivism is an important force in determining teamwork performance given the multicultural environment, consisting of local and foreign workers. This implies when an organization is working with a diverse culture, it would give an opportunity to provide mutual benefits to local and foreign employees.

As with any research initiative, this study is not without limitation. First, a limitation is closely related to language and communication barrier while collecting data. As this study was cross-cultural and the unit of analysis was casual ethnic restaurants, the respondents lack in proficiency to communicate whether in local or English language. For this reason, future studies should provide a bilingual or multilingual set of questionnaire compatible with respondent's verbal communication. Second, a limitation is related to the contextual setting of the study. As the data was limited because it was collected among the employees at the selected restaurants within selected districts of Selangor, the result therefore cannot be generalized to other sample across the nations and sectors. Hence, if one is given ample time, the same study could be undertaken with a larger sample size from different regions within the same area of studies. Particularly, the more samples represent the industry, the more it will improve the generalizability of the findings.

\section{REFERENCES}

Alesina, A., \& La Ferrara, E. (2005). Ethnic diversity and economic performance. Journal of Economic Literature, 43(3), 762-800.

Barak, M. E. M. (2013). Managing diversity: Toward a globally inclusive workplace. Thousand Oaks: Sage Publications.

Bhadury, J., Mighty, E. J., \& Damar, H. (2000). Maximizing workforce diversity in project teams: A network flow approach. Omega, 28, 143-153.

Campion, M. A., Medsker, G. J., \& Higgs, A. C. (1993). Relations between work group characteristics and effectiveness: Implications for designing effective work groups. Personnel Psychology, 46, 823-850.

Dienes, D., \& Velte, P. (2016). The impact of supervisory board composition on CSR reporting. Evidence from the German two-tier system. Sustainability, 8(1), 1-20. DOI: https://doi.org/10.3390/su8010063.

Latif, Z. A. (2019). The Effect of Collectivism Diversity Towards Multicultural Teamwork Performance Among Restaurant Employees. Journal of Vocational Education Studies, 2(2), 91-100. DOI: https://doi.org/10.12928/joves.v2i2.1180. 
Eze, F., Okonkwo, O. M. L., Oluchi, M. L., \& Igwebuike, E. C. (2019). Effect of workforce diversity on the competitiveness of Nigerian Bottling Company South East, Nigeria. International Academy Journal of Management, Marketing and Entrepreneurial Studies, 7(1), 8-24.

Hair, J. F., Black, W. C., Babin, B. J., \& Anderson, R. E. (2010). Multivariate Data Analysis Seventh Edition. Upper Saddle River: Prentice Hall.

Hamid, B. A. (2009). The identity construction of women/maids in domestic help for hire discourse in selected Malaysian newspapers. European Journal of Social Sciences, 9(1), 168-180.

Higgs, M. (1996). Overcoming the problems of cultural differences to establish success for international management teams. Team Performance Management: An International Journal, 2(1), 36-43.

Kahane, L., Longley, N., \& Simmons, R. (2013). The effects of coworker heterogeneity on firm-level output: assessing the impacts of cultural and language diversity in the National Hockey League. Review of Economics and Statistics, 95(1), 302-314.

Kirkman, B. L., \& Shapiro, D. L. (2005). The impact of cultural value diversity on multicultural team performance. Academy of Management Journal, 18, 33-67.

Kreitner, R., \& Kinichi, A. (2004). Organizational Behaviour. Boston: McGraw-Hill.

Lavaty, S., \& Kleiner, B. H. (2001). Managing and understanding the French employee. Management Research News, 24(3/4), 45-48.

Lazear, E. (1999). Culture and language. Journal of Political Economy, 107(6), 29-95.

Maznevski, M. L., Distefano, J. J., Gomez, C. B., Noorderhaven, N. G., \& Wu, P.-C. (2002). Cultural dimensions at the individual level of analysis: the cultural orientations framework. International Journal of Cross-Cultural Management, 2, 275-295.

Noordin, F. \& Jusoff, K. (2010). Individualism-collectivism and job satisfaction between Malaysia and Australia. International Journal of Educational Management, 24(2), 159-174.

Norton, K., \& Olds, T. (1996). Anthropometrica: A textbook of body measurement for sports and health courses. Sydney: UNSW Press.

Nunnally, J. (1978). Psychometric methods. New York: McGraw Hill.

Pallant, J. (2010). SPSS survival manual: A step by step guide to data analysis using SPSS (4th ed.). Maidenhead: Open University Press/McGraw-Hill.

Raudenbush, S. W., \& Bryk, A. S. (2002). Hierarchical linear models: Applications and data analysis methods (2nd ed.). Thousand Oaks: Sage Publications.

Rajagopal, M. (2019). Negara 'dijajah' pendatang tanpa izin secara senyap. Berita Harian Online. $\quad$ Retrieved from: https://www.bharian.com.my/rencana/komentar/2019/03/542744/negaradijajah-pendatang-tanpa-izin-secara-senyap.

Timmermans, B., Ostergaard, C. R., \& Kristinsson, K. (2011). Does a different view create something new? The effect of employee diversity on innovation. Research Policy, $8(54), 500-509$.

Tröster, C., Mehra, A., \& van Knippenberg, D. (2014). Structuring for team success: The interactive effects of network structure and cultural diversity on team potency and performance. Organizational Behavior and Human Decision Processes, 124(2), 245255.

Latif, Z. A. (2019). The Effect of Collectivism Diversity Towards Multicultural Teamwork Performance Among Restaurant Employees. Journal of Vocational Education Studies, 2(2), 91-100. DOI: https://doi.org/10.12928/joves.v2i2.1180. 
Tsui, A. S., \& Ashford, S. J. (1994). Adaptive self-regulation: A process view of managerial effectiveness. Journal of Management, 20, 93-121.

Latif, Z. A. (2019). The Effect of Collectivism Diversity Towards Multicultural Teamwork Performance Among Restaurant Employees. Journal of Vocational Education Studies, 2(2), 91-100. DOI: https://doi.org/10.12928/joves.v2i2.1180. 